\title{
Analysis of The Level of Slum Area in Subulussalam City
}

\author{
Teuku Jaswadi ${ }^{1}$, Lita Sri Andayani ${ }^{2}$, Rujiman $^{2}$ \\ ${ }^{1}$ Master Student in Universitas Sumatera Utara (USU), Medan, Indonesia \\ ${ }^{2}$ Lecturer in Universitas Sumatera Utara (USU), Medan, Indonesia \\ Email: amir.khan1729@yahoo.co.id
}

\begin{abstract}
:
This study aims to analyze the level of slum area in Subulussalam City. The location of the study is conducted in Subulussalam City, Aceh Province, based on the Decree of the Mayor of Subulussalam No. 188.45 / 101/2014 concerning the determination of the location of slums in Subulussalam City, there are 5 slum areas with a total area of 61.77 hectares spread across 5 villages in 5 sub-districts which receive priority handling of slums through the KOTAKU program. The result shows that slum areas in Subulussalam City showed similarities with the results of Anggara's analysis (2018) of slum areas in Tanjung Beringin District, Serdang Bedagai Regency, which is at Medium slum level with a score of 64 .
\end{abstract}

Keywords :

level of slum; Subulussalam City

\section{Introduction}

Subulussalam City is one of the urban administration areas that gets government priority in handling housing and slums. The seriousness of the government in handling slum area can be proven by the launching of national programs based on community empowerment in Subulussalam City, including: (1) Program Nasional Pemberdayaan Masyarakat Mandiri Perkotaan (PNPM-MP), Program Penataan Permukiman Berbasis Komunitas (PLPBK), dan (3) Program Kota Tanpa Kumuh (KOTAKU).

Program Nasional Pemberdayaan Masyarakat Mandiri Perkotaan (PNPM-MP) is the first program carried out by the government through the Ministry of Public Works in an effort to tackle problems in the housing and settlement sector in the City of Subulussalam. The PNPM-MP program is a continuation of the implementation of Program Penanggulangan Kemiskinan di Perkotaan (P2KP) as an effort to sustain the government to build community and local government independence in alleviating poverty since 2009 in the City of Subulussalam. Urban PNPM Mandiri aims to improve the welfare of the community by providing employment opportunities for the poor independently and helping the poor in 73 villages in Subulussalam City (PKP Satker, PUPR Subulussalam City, 2014).

The second program that has been carried out by the government in dealing with housing and slums problems in the City of Subulussalam is the implementation of Program Penataan Permukiman Berbasis Komunitas (PLPBK). This program is one of the PNPM Urban Urban intervention programs initiated by the Directorate of Building and Environmental Arrangement (PBL) of the Ministry of Public Works in 2013, to build an independent community towards civil society, namely the community order in collaboration with local governments and other stakeholders in realizing the environment settlement that is self-made, sustainable, healthy and productive. The PLPBK program aims to realize improvements in the quality of life of the poor through structured, safe and healthy settlement environments. The PLPBK program was 
implemented in Subulussalam City from 2014 to 2015. PLPBK program has allocated funds in the form of Bantuan Langsung Masyarakat (community direct assistance) (BLM) in the amount of 2 (two) billion to each of 2 (two) villages in Subulussalam City namely Suka Makmur Subdistrict Simpang Kiri and Lae Motong Village, Penanggalan District. In addition, this program requires local governments to share programs / budgets of $50 \%$ of stimulant assistance allocated to each village, so that each village receives a budget / program allocation of 1.5 billion rupiahs whose concept of use is to: (a) efforts to realize behavioral changes and improve the quality of life of the poor through improving the quality of the housing environment and the scope of services for adequate, productive and sustainable housing infrastructure, and (b) focusing on improving the quality of the housing environment and housing infrastructure service coverage at the village community level, particularly in priority areas poor who guarantee the benefit of the program for the poor and improve community welfare (Satker PKP, Sub -ussalam City PUPR Office, 2014).

\section{Literature Review}

\subsection{Slums Area}

Slum areas can be interpreted as a residential area with a high population density in a city that is generally inhabited by poor people. Slums can be found in various major cities in the world. Slum areas are generally associated with poverty and high levels of poverty. Slum settlement areas can also be a source of social problems such as crime, drugs and alcohol. In many poor countries, slums are also a center of health problems because of their unhygienic conditions.

The term "slum" earlier began to emerge in England in 1880, when the housing reform movement was incessantly stating several operational concepts related to housing materials that were not suitable for human life. The point is that housing service standards in the country are deemed to have not met the feasibility, especially in terms of the technical provision of building materials. This gave rise to the idea that slums had to be included in the mapping of a city planning contained in the urban development agenda. So based on the actions of the reform movement in the UK, several other countries have begun to glance at how the problem of slums has become a matter that must be handled appropriately and appropriately (Prayitno, 2014).

In the Big Indonesian Dictionary $(\mathrm{KBBI})$, slums are dirty. Explanation of the meaning of polluted or dirty is intended on the condition or nature of an area, village and so forth that are not arranged so beautifully. If it is simplified again that slum is a condition of an area, village etc. that is not well ordered because it is caused by pollution. Other acquisitions, opinions about slums and slums, have also been raised by experts, regulations and institutions. other official.

Acharya (2010) defines slums as inadequate housing due to the absence of physical facilities (RTH, drainage, clean water supply, communication networks, etc.) and social facilities (social organizations, health, and so on). The slum life has not only affected developing countries but also the developed ones (Srivastava \& Singh, 2007).Slums are areas where houses and community housing conditions in the area are very bad. The existing houses and facilities and infrastructure are not in accordance with applicable standards, both the standard requirements, building density, healthy house requirements, the need for clean water facilities, sanitation and the requirements for completing road infrastructure, open space, and other social facilities (Putro, 2011). 


\subsection{Identification of Slum Areas}

Summarizing some views on the characteristics and characteristics of slum areas which subsequently becomes the basis for the formulation of criteria and indicators of slum symptoms in the process of identifying slum areas as described previously, it is necessary to identify slums, especially physically based on stages of slum criteria. The identification of slum problems is an identification stage to determine the slum problems in the object of study that is focused on aspects of the physical quality of buildings and infrastructure in a location. The identification of slum problems is based on consideration of the notions of slums and slums, technical requirements in accordance with applicable regulations, as well as minimum service standards required nationally based on the following criteria (Permen PUPR No. 2 of 2016):

\section{A. The condition of buildings, with criteria including:}

1) Building irregularity. It is a condition of buildings in settlements that do not meet the building layout requirements in Rencana Detail Tata Ruang (RDTR) and Rencana Tata Bangunan dan Lingkungan (RTBL), at least setting the shape, size, placement, and appearance of the building in a zone.

2) Building density: The high level of building density that is not in accordance with the provisions of the spatial plan is the condition of buildings in housing and settlements with:

- Koofisien Dasar Bangunan (KDB) that exceeds the RDTR provisions. KDB is a percentage ratio between the area of the entire ground floor of a building that can be built with the area of land occupied.

- Koofisien Lantai Bangunan (KLB) that exceeds the provisions in the RDTR. KLB is a percentage ratio between the total number of floors of buildings that can be built with the area of land occupied.

3) Incompatibility with building technical requirements. Is the condition of buildings in housing and settlements that are not in accordance with technical requirements which include: controlling environmental impacts; construction of buildings above and / or below ground, water and / or public infrastructure / facilities; building safety; building health; the comfort of the building; and ease of building.

\section{B. Environmental road conditions, with criteria including:}

1) Coverage of environmental road services. The neighborhood road network does not serve the entire residential or settlement environment.

2) Quality of road surface environment. Is the condition of part or all of the environmental road damage to the road surface.

\section{The condition of drinking water supply, with the criteria:}

1) Availability of safe access to drinking water. It is a condition where people cannot access drinking water that has a colorless, odorless, and tasteless quality.

2) Unfulfilled drinking water needs. This is a condition where the need for community drinking water in a residential and residential environment does not reach a minimum of 60 liters / person / day.

\section{Environmental drainage conditions, with criteria including:}

1) Unable to drain water runoff. Environmental drainage conditions are not able to drain water runoff so that it can cause standing water. 
2) Unavailability of drainage. Is a condition where primary, secondary and tertiary channels are not available.

3) Unrelated to the city drainage system. It is a condition where the tertiary and secondary channels cannot be connected to the primary (primary) channel, so that the secondary and tertiary darinase channels become blocked and inundated.

4) No drainage can be maintained. Poorly maintained drainage results in the accumulation of solid waste and liquid waste in it.

5) Quality of drainage construction. Is a condition of a channel made of permanent material, and is able to withstand the flow of water discharge.

\section{E. Wastewater management conditions, with criteria including:}

1) The wastewater management system is not in accordance with technical standards. Is a condition of waste water management in the environment and housing does not have an adequate system

2) Waste water management infrastructure and facilities are not in accordance with technical requirements. Is the condition of facilities and infrastructure that do not meet health standards.

\section{F. Waste management conditions, with criteria including:}

1) Solid waste infrastructure and facilities are not in accordance with technical requirements. It is a condition of solid waste facilities and infrastructure that do not meet construction technical standards, resulting in solid waste.

2) Waste management system that is not in accordance with technical standards. Is a condition of unsustainable waste management.

3) Waste management facilities and infrastructure are not maintained. It is a situation and condition where waste facilities and infrastructure are not maintained according to technical standards, and have an impact on damage to waste facilities.

\section{G. Conditions for fire protection, with criteria including:}

1) Unavailable fire protection infrastructure. Conditions where the unavailability of fire safety infrastructure in the form of water sources both from nature and artificial reservoirs.

2) Unavailability of fire protection facilities Conditions where there are no fire extinguishers in the form of fire trucks, fire engines and other supporting equipment.

\subsection{Definition of Program}

As explained earlier, the KOTAKU program is a strategic program initiated by Direktorat Jenderal Cipta Karya Kementerian Pekerjaan Umum dan Perumahan Rakyat to accelerate the handling of slums nationally in 34 provinces in 271 districts / cities in supporting the "100-0 Movement - 100 ", i.e. 100 (one hundred) percent universal access to drinking water, 0 (zero) percent of slums, and 100 (one hundred) percent access to proper sanitation. This program intends to build an integrated system for handling slums, where local governments lead and collaborate with stakeholders in planning and implementation, as well as promoting community participation. (SE DJCK PUPR No. 40 / SE / DC / 2016).

\subsection{Community Participation}

Participation is the mental and emotional involvement of people in a group that encourages them to contribute to the community in an effort to achieve goals and take responsibility for the business concerned (Sastropoetra, 1998). Mubyarto in Sastropoetra (1988) also stated that 
participation as a willingness to help the success of each program in accordance with the ability of each person without sacrificing self-interest.

According Soemadiningrat (1996) in Augustine (2003) argues that participation is the willingness of the people to absolutely support government programs or projects that are designed and determined by the government. Furthermore Koentjaraningrat in Sastropoetra (1988), argues that participation means contributing and helping determine the direction or purpose of development, which emphasizes that participation is a right and obligation for the community. Meanwhile, according to Affan (1993) provides an understanding that participation is the level of involvement of members of the social system collectively in the decision making process and the implementation of the decision.

From some of the above understanding important elements of the concept of participation are the mental and emotional involvement of the community, motivating people to contribute, helping the success of every program that is run, and the involvement of members of the social system collectively in the decision making process. If it is associated with a particular area, participation can be interpreted as community involvement as a social system in a particular area / region, mentally, emotionally, materially both individually (or individually) or in groups in a certain condition to achieve a goal that has been mutually agreed upon between the organizers and that community.

\subsection{Planning}

Handayaningrat in Safi'i (2007) defines planning as a decision for the future, what will be done, when it will be done and who will do it. According to Safi'i (2007) the definition of planning is a process to prepare systematically with awareness of the use of limited resources but is oriented to achieving goals effectively and efficiently, where to achieve the objectives requires accurate policy formulation. Etzioni in Safi'i (2007) argues that in planning theory there are several typologies, including rational planning models; incrementalplanning model; and strategic planning model.

\subsection{Regional Planning}

Sirojuzilam (2008) argues, in principle regional planning is the application of planning in a location in this case the region or region. Very successful development and development efforts if supported by a good regional planning. Regional planning in various countries is not the same, depending on economic life and the problems faced. Historically there have been at least three regional planning approaches (Jayadinata, 1999), namely:

A) Regional planning that focuses on urban problems that are social in nature. Its implementation includes repairing parts of the city that have been damaged and not meeting standards, renovation of the city, making a satellite city to help alleviate an overly populated industrial city. The emphasis of this kind of regional planning is on large cities and surrounding areas (hinterland) that can support cities in urban and regional planning.

B) Regional planning that focuses on areas where the population is largely unemployed and in a state of industrial stagnation (special areas). In such areas, the government needs to regulate intensive financing, arrange stimuli for industrial infrastructure, regulate tax concessions and so on, so that certain industries can be located in the region. 
C) Regional planning that takes into account rural areas, with land development for the agriculture and recreation sector (rural and regional planning). This is done to minimize the difference in prosperity between rural and urban areas.

\section{Research Methods}

The location of the study was conducted in Subulussalam City, Aceh Province, based on the Decree of the Mayor of Subulussalam No. 188.45 / 101/2014 concerning the determination of the location of slums in Subulussalam City, there are 5 slum areas with a total area of 61.77 hectares spread across 5 villages in 5 sub-districts which receive priority handling of slums through the KOTAKU program. The 5 regions can be explained in the following table, namely:

Table 1. Areas and Slum Areas of Subulussalam City Based on Slum Decree

\begin{tabular}{clll}
\hline No. & Slum Are/Village & Sub-District & Area $(\mathrm{Ha})$ \\
\hline 1. & Subulussalam Utara & Simpang Kiri & $\mathbf{1 5 , 4 6}$ \\
2. & Lae Ikan & Penanggalan & $\mathbf{2 0 , 6 6}$ \\
3. & Pasar Rundeng & Rundeng & $\mathbf{1 0 , 1 9}$ \\
4. & Suka Maju & Sultan Daulat & $\mathbf{9 , 6 3}$ \\
$\mathbf{5 .}$ & Longkip & Longkib & $\mathbf{5 , 8 3}$ \\
\hline Total & & & 61,77 \\
\hline Source: & data processed according to Decree of Mayor of Subulussalam No. $188.45 / 101 / 2014$
\end{tabular}

Population is a generalization area consisting of objects / subjects that have certain qualities and characteristics determined by researchers to be studied, and then conclusions are drawn. So the population is not only people, but also objects and other natural objects. The population is also open only to the number of objects / subjects studied, but includes all the characteristics / properties possessed by the subject or object under study (Sugiyono, 2013, 90).

In this study, the population is all households that will be respondents in 5 slum areas, namely 855 households (KOTAKU Baseline Data, Subulussalam Slum Area 2018). The following table describes data on the number of household slums in 5 slums, that is:

Table 2. Data on the Number of Household Populations

\begin{tabular}{cllll}
\hline No. & Slum Are/Village & \multicolumn{1}{c}{ Sub-District } & Area (Ha) & $\begin{array}{c}\text { Total Population } \\
\text { (Family } \\
\text { Card/Respondents) }\end{array}$ \\
\hline 1. & Subulussalam Utara & Simpang Kiri & $\mathbf{1 5 , 4 6}$ & $\mathbf{2 0 5}$ \\
2. & Lae Ikan & Penanggalan & $\mathbf{2 0 , 6 6}$ & $\mathbf{7 0}$ \\
3. & Pasar Rundeng & Rundeng & $\mathbf{1 0 , 1 9}$ & $\mathbf{8 8}$ \\
\hline 4. & Suka Maju & Sultan Daulat & $\mathbf{9 , 6 3}$ & $\mathbf{4 2 4}$ \\
\hline 5. & Longkip & Longkib & $\mathbf{5 , 8 3}$ & $\mathbf{6 8}$ \\
\hline Total & & & 61,77 & 855 \\
\hline
\end{tabular}

Source: Kotaku Baseline Data, Slum Area in Subulussalam City, 2018.

The sample is part of the number and characteristics possessed by the population. If the population is large, and researchers may not study everything in the population, for example due to limited funds, manpower and time, then researchers can use samples taken from that 
population. What is learned from the sample, the conclusion can be applied to the population. For samples taken from the population must be truly representative (Sugiyono, 2013: 91). Roscoe (1975) in Uma Sekaran (1992) provides guidelines for determining the number of samples between 30 to 500 elements. If the sample is broken down again into subsamples (male / female, elementary / junior / senior high school, etc.), the minimum number of subsamples must be 30. One method used to determine the sample size that meets the count is by using the Slovin formula. The following is calculating the sample size by using the slovin formula:

$$
\mathrm{n}=\frac{\mathrm{N}}{1+\mathrm{Ne}^{2}}
$$

Where : $\mathrm{N}=$ sample size

$$
\begin{aligned}
\mathrm{N} & =\text { population size } \\
\mathrm{E} & =\text { batas toleransi kesalahan (error tolerance) with a precession value } \\
& 10 \%(0,1)
\end{aligned}
$$

Calculation

$$
\begin{aligned}
& \mathrm{n}=\frac{855}{1+\left(855 \times 0,1^{2}\right)}=\frac{855}{1+(855 \times 0,01)}=\frac{855}{1+(8,550)} \\
& \mathrm{n}=\frac{855}{9,550}=\quad 89,52 . \text { Then it can be rounded off to } 90
\end{aligned}
$$

From 90 samples taken were elements of family card/ other respondents, distributed to the 5 slum areas. The number of respondents was taken based on the Quota Sampling. the total population and study sample can be seen in the following table 3:

Table 3. Number of Population and Sample Data by Village / Slum Area

\begin{tabular}{clllll}
\hline No. $\begin{array}{llll}\text { Village/ } \\
\text { Area }\end{array}$ & Slum & Sub-Distric & $\begin{array}{l}\text { Area } \\
(\mathrm{Ha})\end{array}$ & $\begin{array}{c}\text { Total Population } \\
\text { (Family } \\
\text { Card/Respondents) }\end{array}$ & $\begin{array}{c}\text { Sample Total } \\
\text { (Family } \\
\text { Card/Respondents) }\end{array}$ \\
\hline 1. & $\begin{array}{l}\text { Subulussalam } \\
\text { Utara }\end{array}$ & $\begin{array}{l}\text { Simpang } \\
\text { Kiri }\end{array}$ & $\mathbf{1 5 , 4 6}$ & $\mathbf{2 0 5}$ & $\mathbf{2 0}$ \\
2. & Lae Ikan & $\begin{array}{l}\text { Penanggala } \\
\text { n }\end{array}$ & $\mathbf{2 0 , 6 6}$ & $\mathbf{7 0}$ & $\mathbf{8}$ \\
3. & Pasar Rundeng & Rundeng & $\mathbf{1 0 , 1 9}$ & $\mathbf{8 8}$ & $\mathbf{1 0}$ \\
4. & Suka Maju & $\begin{array}{l}\text { Sultan } \\
\text { Daulat }\end{array}$ & $\mathbf{9 , 6 3}$ & $\mathbf{4 2 4}$ & $\mathbf{4 4}$ \\
$\mathbf{5}$ & Longkip & Longkib & $\mathbf{5 , 8 3}$ & $\mathbf{6 8}$ & $\mathbf{8}$ \\
\hline \multicolumn{2}{|c|}{ Total } & & 61,77 & 855 & 90 \\
\hline
\end{tabular}

Source: Kotaku Baseline Data, Slum Area in Subulussalam City, 2018.

\section{Discussion}

The level of slums analyzed in the formulation of the fourth problem is closely related to the third research objective about the physical condition of the slums. Where in calculating the level of slum in this slum area, the authors use the Baseline Numerical Data 100-0-100 slum area of Subulussalam City which has been detailed by data according to aspects and indicators of slum in 5 slum areas. The available data is then processed and calculated by referring to the calculation formula stipulated in PUPR Minister Regulation No. 2 of 2016. 
Before determining the results of the analysis of the average level of slums in the slums in Subulussalam, the authors first formulated and calculated the slum levels in each slum area. The results of calculations regarding the level of slums can be noted based on the following subchapters:

\subsection{The Level of Slum Area in Subulussalam City}

The level of slum identified in North Subulussalam city is in the Normal classification, where the results of the calculation of the 7 aspects of slum facilities and infrastructure in the area obtained a value of 35 , at an interval with a score between 19-44.

Table 4. Calculation of the level of slum area of North Subulussalam

\begin{tabular}{clll}
\hline No. & Aspect of Slum & Score of Slum & Classification \\
\hline 1. & Building & $1+1+1$ & \\
2. & Road Environment & $1+1$ & \\
3. & Availability of Drinking Water & $5+5$ & Interval (Score) \\
4. & Environmental Drainage & $1+1+1+1+1$ & $19-44$ \\
5. & Waste Water Management & $1+1$ & \\
6. & Solid Waste Management & $5+5+1$ & \\
7. & Fire Protection & $1+1$ & Normal \\
\hline & Total & 35 & \\
\hline
\end{tabular}

Source: Analysis Result, 2019

\subsection{The Level of Slum in Area of Lae Ikan}

The level of slum identified in Lae Ikan slum area is in the Normal classification, where the calculation results from the formulation of 7 aspects of slum facilities and infrastructure in the area obtained a value of 41 , at an interval with a score between 19-44.

Table 5. Calculation of the Level of Slum in Lae Ikan Area

\begin{tabular}{clll}
\hline No. & \multicolumn{1}{c}{ Aspect of Slum } & \multicolumn{1}{c}{ Score of Slum } & Classification \\
\hline 1. & Building & $3+1+1$ & \\
2. & Road Environment & $1+1$ & \\
3. & Availability of Drinking Water & $1+5$ & Interval (Score) \\
4. & Environmental Drainage & $1+3+1+1+1$ & $19-44$ \\
5. & Waste Water Management & $1+1$ & \\
6. & Solid Waste Management & $5+5+5$ & \\
7. & Fire Protection & $3+1$ & Normal \\
\hline & Total & 41 & \\
\hline
\end{tabular}

Source: Analysis Result, 2019

\subsection{The level of Slum in Pasar Rundeng Area}

The level of slums identified in Pasar Rundeng area is Medium classification, where the calculation results from the formulation of 7 aspects of slum facilities and infrastructure in the area obtained a value of 49 , which is in the interval with a score between 45-70. 
Table 6. Calculation of the Level of Slum of in Pasar Rundeng Area

\begin{tabular}{clll} 
No. & \multicolumn{1}{c}{ Aspect of Slum } & \multicolumn{1}{c}{ Score of Slum } & \multicolumn{1}{c}{ Classification } \\
\hline 1. & Building & $1+1+3$ & \\
2. & Road Environment & $1+1$ & \\
3. & Availability of Drinking Water & $1+5$ & Interval (Score) \\
4. & Environmental Drainage & $1+1+1+3+3$ & $45-70$ \\
5. & Waste Water Management & $5+5$ & \\
6. & Solid Waste Management & $5+5+5$ & \\
7. & Fire Protection & $1+1$ & Medium \\
\hline & Total & 49 & \\
\hline
\end{tabular}

Source: Analysis Result, 2019

\subsection{The Level of Slums in Suka Maju Area}

The level of slums identified in Suka Maju Area is in Medium classification, where the calculation results from the formulation of 7 aspects of slum facilities and infrastructure in the area obtained a value of 61, which is in the interval with a score between 45-70.

Table 7. Calculation of the Level of Slum of Suka Maju Area

\begin{tabular}{llll}
\hline No. & \multicolumn{1}{c}{ Aspect of Slum } & \multicolumn{1}{c}{ Score of Slum } & Classification \\
\hline 1. & Building & $3+3+3$ & \\
2. & Road Environment & $1+1$ & \\
3. & Availability of Drinking Water & $1+5$ & Interval (Score) \\
4. & Environmental Drainage & $1+5+1+1+1$ & $45-70$ \\
5. & Waste Water Management & $5+5$ & \\
6. & Solid Waste Management & $5+5+5$ & \\
7. & Fire Protection & $1+5$ & Medium \\
\hline
\end{tabular}

Source: Analysis Result, 2019

\subsection{The Level of Slums in Longkip Area}

The level of slum identified in the Longkip area is in Medium classification, where the calculation results from the formulation of 7 aspects of slum facilities and infrastructure in the area obtained a value of 69 , which is in the interval with a score between 45-70.

Table 8. Calculation of the Slum Areas of Longkip

\begin{tabular}{llll}
\hline No. & \multicolumn{1}{c}{ Aspect of Slum } & \multicolumn{1}{c}{ Score of Slum } & Classification \\
\hline 1. & Building & $3+3+3$ & \\
2. & Road Environment & $1+5$ & \\
3. & Availability of Drinking Water & $5+5$ & Interval (Score) \\
4. & Environmental Drainage & $1+5+1+1+1$ & $45-70$ \\
5. & Waste Water Management & $5+5$ & \\
6. & Solid Waste Management & $5+5+5$ & \\
7. & Fire Protection & $5+5$ & Medium \\
\hline
\end{tabular}

Source: Analysis Result, 2019 
From the calculation of the level of slum above, that the slum area of Longkip Village shows the highest score among the 5 slum areas with a number of 69 , while the lowest score in the settlement area of Subulussalam Utara Village with a number of 35 . Of the 5 areas indicated 2 areas with levels mild slums namely North Subulussalam and Lae Ikan, while for the other 3 slums, Rundeng, Suka Maju and Longkip markets are indicated with moderate slum levels.

The average level of slum in 5 residential areas in Subulussalam City shows the level of slum, where the results of the calculation of 7 aspects of slum facilities and infrastructure conditions in the 5 areas obtained a value of 51, which is in the interval with a score between 45-70.

The results of the calculation of the average level of slums of Subulussalam City are as follows:

Table 9. Calculation Average of Slum Level in Subulussalam City

\begin{tabular}{lllll}
\hline No. & Village & $\begin{array}{l}\text { Total Score } \\
\text { Slum }\end{array}$ & $\begin{array}{l}\text { Interval } \\
\text { (Score) }\end{array}$ & Classification \\
\hline 1. & Subulussalam Utara & 35 & $19-44$ & Normal \\
\hline 2. & Lae Ikan & 41 & $19-44$ & Normal \\
3. & Pasar Rundeng & 49 & $45-70$ & Medium \\
4. & Suka Maju & 61 & $45-70$ & Medium \\
5. & Longkip & 69 & $45-70$ & Medium \\
\hline & Total/Average & 51 & $45-70$ & Medium \\
\hline
\end{tabular}

Source: Results of Analysis, 2019

The results of the analysis of the level of slum areas in Subulussalam City showed similarities with the results of Anggara's analysis (2018) of slum areas in Tanjung Beringin District, Serdang Bedagai Regency, which is at Medium slum level with a score of 64.

\section{Conclusion}

The physical condition of the slums in Subulussalam City at the beginning of the KOTAKU program showed many indications of problems, including:

a. In the aspect of housing and residential buildings, it still shows an indication that the number of people who inhabit houses is less feasible both from the construction of buildings and the location of buildings that are not safe for residents such as being on the banks of a river.

b. In the aspect of environmental roads, there are still housing and settlements that are not served by environmental roads, dirt road surface, narrow, and the number of damaged roads caused by the unavailability of drainage networks, which causes the road body to be flooded.

c. In the aspect of access to clean water / drinking water, there is still a lack of clean water services as consumption water to the community, many households still use dug wells, and there are still households that collect rainwater as consumption water, and there are households that still use river water as water consumption, especially for the Pasar Rundeng, Suka Maju and Longkip areas.

d. In the drainage network aspect, most of the slum areas are in a damaged condition, and there are some environments that do not have drainage channels. 
e. In the aspect of access to household wastewater, it is still relatively low to use family toilets, causing many people to use nature as a place for household waste disposal.

f. In the aspect of waste management, all households in the slums area are categorized as not having solid waste facilities, so that households still litter and or burn it.

g. In the aspect of fire protection, some locations do not have access to fire safety, the unavailability of Light Fire Extinguishers in RT, as well as inadequate access to roads for fire fighting vehicles.

\section{References}

Adina, Sari. (2010). KajianKarakteristikPemukimKumuh Dan Liar Di PerkotaanStudiKasus :KelurahanTegal Sari Mandala II Kecamatan Medan Denai Kota Medan. (Tesis). Universitas Sumatera Utara. Program Pascasarjana

Advianty dan Ketut, H. (2013). Tingkat Partisipasi Masyarakat pada Permukiman Kumuh Kelurahan Ploso. (Jurnal Teknik). Institut Teknologi Sepuluh November

Anggara, Vivut. (2018). Analisis Tingkat Kekumuban dan Strategi Penanganan Kawasan Permukiman Kumub di Kecamatan Tanjung Beringin Kabupaten Serdang Bedagai. (Tesis). Universitas Sumatera Utara. Program Pascasarjana

Amelia, Itani. (2017). Analisis Faktor-faktor Yang Mempengarubi Partisipasi Masyarakat Dalam Keberbasilan Program Kota Tanpa Kumub/ KOTAKU (Studi Kasus di Kelurahan Kebon dalem Kota Cilegon dan Kelurahan Lontar Baru Kota Serang Provinsi Banten. (Tesis). Universitas Sumatera Utara. Program Pascasarjana

Arikunto, S. (2010). Prosedur Penelitian: Suatu Pendekatan Praktek. Rineka Cipta. Jakarta

Azhari, Samlawi. 1997. EtikaLingkunganDalam Pembangunan Berkelanjutan. Tut Wuri handayani. Jakarta

Bappeda Kota Subulussalam.Rancangan Tata Ruang Wilayah Tabun 2013.

Bappenas. Dokumen Strategi Nasional Penanggulangan Kemiskinan (SNPK) Tabun 2005.

BPS. Kota Subulussalam Dalam Angka Tahun 2018

BPS. Longkib Dalam Angka Tahun 2018

BPS. Rundeng DalamAngkaTahun 2018

BPS. Simpang Kiri Dalam AngkaTabun 2018

BPS. Sultan Daulat Dalam Angka Tahun 2018

BPS. Penanggalan Dalam Angka Tabun 2018

Budiharjo, Eko. (1984). Sejumlah Masalah Permukiman Kota. Penerbit Alumni. Bandung

Budiharjo, Eko. (1997). Tata Ruang Perkotaan. Penerbit Alumni. Bandung

Crysta. E.A dan Budisusanto. Y. (2017). Identifikasi Permukiman Kumub Berdasarkan Tingkat RT di Keluraban Keputih Kota Surabaya. (Jurnal). Institut Teknologi Sepuluh November. Fakultas Teknik Sipil

Dewi, Risna. (2011). Pengembangan Konsep Pemukiman Berkelanjutan (Studi Kasus di Pemukiman Kumuh Kecamatan Banda Sakti Kota Lhokseumawe). (Tesis). Universitas Sumatera Utara. Program Pascasarjana

Drakakis dan Smith. (1980). Perencanaan Kota, (terjemahan). Penerbit Erlangga. Jakarta

Dwira, Samsul dan Wahyuni. (2008). Bahan Ajar Perumahandan Permukiman. Penerbit USU Press. Medan

Hasrul Rizka, Agus Purwoko dan Rujiman. (2018). Perencanaan Penanganan Kawasan Pemukiman Kumub Di Kelurahan Tanjung Tiram Kabupaten Batubara. (Jurnal). Universitas Sumatera Utara. Program Pascasarjana

Judohusodo, Siswono. (1991). Rumah Untuk Seluruh Rakyat. Penerbit Yayasan Padamu Negeri. Jakarta 
Judohusodo, Siswono. (1991). Timbulnya Permukiman Liar Di Daerah Perkotaan. (Jurnal Imu Sosial). Penerbit Gramedia. Jakarta

Kali, Agustinus. (2011). Analisis Partisipasi Masyarakat Terbadap Perencanaan dan Pembangunan PLTMH di Paneki Desa Pombewe Kecamatan Biromaru Kabupaten Sigi. (Jurnal Teknik). Universitas Tadulako, Palu

Kartasasmita, G. (1997). Pemberdayaan Masyarakat: Konsep Pembangunan yang berakar pada Masyarakat. Bappenas.Jakarta

KBBI. Kamus Besar Bahasa Indonesia 2018

Komarudin. 1997. Menelusuri Pembangunan Perumahan dan Permukiman. Penerbit Yayasan Real Estate Indonesia. Jakarta

Kotaku Kota Subulussalam. Memorandum Program RP2KP-KP Tahun 2017

Kotaku Kota Subulussalam. Data Baseline 100-0-100, Kawasan Permukiman Kumub Tabun 2017

Kumar, Jitendra. (2014). Slums In India: A Focus On Metropolitan Cities. (Terjemahan: International Journal of Development Research, Vol. 4 Edisi 2, Februari 2014). Department Of Geography, KLP College, Rewari, India

Kuncoro, Mudradjad. (2013). Edisi 4. Metode Riset Untuk Bisnis dan Ekonomi. Erlangga. Jakarta

Leon, David A. 2008. Cities, urbanization and health. (International Journal of Epidemiology, Volume 37, Issue 1, February 2008)

Masaro, T Daeng. (2016). Analisis Penanganan Kawasan Kumub Kota Tebing Tinggi. (Tesis). Universitas Sumatera Utara. Program Pascasarjana

Mulia, E. Martha. (2008). Analisis Faktor-Faktor Tekanan Lingkungan Pada Pemukiman Kumub (Studi Kasus Pemukiman Kampung Kubur, Kelurahan Petisab Tengab, Kecamatan Medan Petisah). (Tesis). Universitas Sumatera Utara. Program Pascasarjana

Nursyahbani R dan Pigawati B. (2015). Kajian Karakteristik. Kawasan Permukiman Kumub Di Kampung Kota (Studi Kasus: Kampung Gandekan Semarang). (Jurnal). Universitas Diponegoro. Fakultas Teknik

Prayitno, Budi. (2014). Skema Inovatif Penanganan Permukiman Kumuh. Penerbit Gadjah Mada University Press. Yogyakarta

Republik Indonesia. Peraturan Menteri Pekerjaan Umum dan Perumaban Rakyat Nomor 2 Tabun 2016 tentang Peningkatan Kualitas Terhadap Perumahan Kumub dan Permukiman Kumuh.

Republik Indonesia. Peraturan Presiden Nomor 2 Tabun 2015 tentang Rencana Pembangunan Jangka Menengah Nasional Periode Tabun 2015 - 2019.

Republik Indonesia. Undang-Undang Dasar 1945.

Republik Indonesia. Undang-Undang Nomor 1 Tabun 2011 tentang Perumahan dan Kawasan Permukiman.

Rindarjono, Gamal. (2017). Slum. Kajian Permukiman Kumub Dalam Perspertif Spasial. Penerbit Media Perkasa. Yogyakarta

Sahid, R. (2011). Analisis Data Penelitian Kualitatif Model Miles dan Huberman. UMS. Sekolah Pascasarjana

Sastra. S, Endy M. (2005). PerencanaandanPengembanganPerumahan.

Sastropoetro, RA, Santoso. (1988). Partisipasi, komunikasi, Persuasi, danDisiplindalam Pembangunan. Penerbit Alumni. Bandung.

Srivastava, A., \& Singh, R.C. (2007). Slums and Associated Problems: A Case Study of Bhilai, an Industrial City, India. International Journal of Enviromental Studies, 51-60.

Sinulingga. 2005. Pembangunan Kota, Tinjauan Regional dan Lokal. Penerbit Pustaka Sinar Harapan. Jakarta

Sirojuzilam. (2005). Regional Planning dan Development. Wabana Hijau. Perencanaan Pengembangan Wilayah (Jurnal) Vol.1.1 Nomor 1 Agustus 2005

Sugiyono. 2008. Metode Penelitian Administrasi Kuantitatif, Kualitatif dan R \& D. Penerbit Alfabeta. Bandung. 
Supriatna, Tjahya. (2000). Birokrasi, Pemberdayaan, dan Pengentasan Kemiskinan. Penerbit Humaniora Utama Press. Bandung

Surat Edaran Direktorat Jenderal Cipta Karya Kementerian Pekerjaan Umum dan Perumahan Rakyat Nomor: 40/SE/DC/2016. Tentang Pedoman Umum Program Kota Tanpa Kumuh.

Surat Keputusan Walikota Subulussalam Nomor: 188.45/101/2014. Tentang Penetapan Lokasi Perumahan Kumuh dan Permukiman Kumuh.

Surtiani, E. Endang. (2006). Faktor-faktor Yang Mempengarubi Terciptanya Kawasan Permukiman Kumuh Di Kawasan Pusat Kota (Studi Kasus: Kawasan Pancuran, Kota Salatiga) (Tesis). Universitas Diponegoro. Program Pascasarjana

Syafe'i .H.M. (2007). Strategi dan Kebijakan Pembangunan Ekonomi Daerah. Perspektif Teoritik. Penerbit Averroes Press. Malang

Widyonindito, Sigit. (2003). Kajian Partisipasi Masyarakat Dalam Program Penataan Lingkungan Permukiman Kumuh Di Kelurahan Rejowinangun Selatan Kota Magelang. (Tesis). Universitas Diponegoro. Program Pascasarjana

Wiratna, Sujarweni. (2014). Metode Penelitian Lengkap, Praktis dan Mudah Difahami. Penerbit Pustaka Baru Press. Yogyakarta

Yunizar. (2001). Partisipasi Masyarakat Dalam Pelaksanaan Pengelolaan Sampah di Kota Binjai (Tesis). Universitas Sumatera Utara, Program Pascasarjana.

Yunus, Hadi Sabari. (2005). Manajemen Kota: Perspertif Spasial, Penerbit Pustaka Pelajar. Yogyakarta Yunus, Hadi Sabari. (2012). Slum. Kajian Permukiman Kumub Dalam Perspektif Spasial, PenerbitMedia Perkasa. Yogyakarta

http://perencanaankota.blogspot.com/pengertian-pemukiman-kumuh.html. accessed 22 July 2018

http://misterpenelitian.blogspot.com/2015/05/landasan-teori-kerangka-pikir dan.html. accessed 23 December 2018

http://retnokartikasari717.blogspot.com/2015/06/permukiman-kumuh.html. accessed 22 July 2018

http://sangit26.blogspot.com/2011/07/analisis-data-penelitian-kualitatif.html. accessed 16 September 2018 